\title{
B-Type Natriuretic Peptide in Bronchiolitis: Its Relationship with Left Ventricular Systolic Functions and Prognosis
}

\author{
Orta-Ağır Bronşiyolitli Hastalarda Plazma B-Tipi Natriüretik Peptid Düzeyleri ile Sol \\ Ventrikül Sistolik Fonksiyonları ve Hastalık Seyri Arasındaki Ilişki
}

\author{
(D) Gülşen Kes ${ }^{1}$, (D) Gülser Esen Besli², (D) Yusuf İzzet Ayhan ${ }^{3}$, (D) Nurdan Erol ${ }^{3}$, (D) Ferruh Kemal İşman ${ }^{4}$ \\ 1istanbul Medeniyet University Göztepe Training and Research Hospital, Clinic of Pediatrics, Istanbul, Turkey \\ 2 Istanbul Medeniyet University Göztepe Training and Research Hospital, Clinic of Pediatric Emergency, Istanbul, Turkey \\ 3 Istanbul Medeniyet University Göztepe Training and Research Hospital, Clinic of Pediatric Cardiology, Istanbul, Turkey \\ 4 istanbul Medeniyet University Göztepe Training and Research Hospital, Clinic of Biochemistry, Istanbul, Turkey
}

\section{Abstract}

Introduction: We have limited information about the clinical importance of plasma B-type natriuretic peptide (BNP) level and its prognostic value in children with bronchiolitis. In this study, we aimed to determine basal plasma BNP levels and their relationship with left ventricular systolic functions and prognosis in patients hospitalized with moderate to severe bronchiolitis.

Methods: The study was conducted prospectively on 37 patients aged 1-24 months with a modified Wang respiratory score of 6 and above and diagnosed with bronchiolitis. The patients with high $(>100 \mathrm{pg} / \mathrm{mL}, \mathrm{n}=6)$ and normal $(\leq 100 \mathrm{pg} / \mathrm{mL}, \mathrm{n}=31)$ serum BNP levels were compared in terms of left ventricular systolic functions, and vital, laboratory, and radiological findings. The relationship between serum BNP level and prognosis was evaluated.

Results: The mean basal plasma BNP level in the patients was significantly higher than in controls $(61.75 \pm 65 \mathrm{pg} / \mathrm{mL}$ vs. $13.99 \pm 8.79$ $\mathrm{pg} / \mathrm{mL} ; \mathrm{p}=0.001)$. There was no significant difference in ejection fraction and fractional shortening values between the patients with normal and high BNP levels and controls $(p>0.05)$. Patients with high BNP levels had higher mean partial carbon dioxide values than patients with normal BNP levels $(p=0.037)$. There was a positive correlation between plasma BNP level and length of hospital stay $(r=0.286 ; p=0.007)$ and intensive care unit stay $(r=0.645 ; p=0.000)$. Conclusion: An increase in serum BNP levels may be seen in patients with moderate to severe bronchiolitis without myocardial dysfunction. It was argued that this BNP increase may be related to the degree of deterioration of gas exchange associated with the disease. Plasma BNP level is a potential prognostic factor in moderate to severe bronchiolitis.

Keywords: Bronchiolitis, infant, B-type natriuretic peptide, myocardial dysfunction, prognosis

\section{Öz}

Giriş: Bronşiyolitli hastalarda plazma B tipi natriüretik peptid (BNP) düzeyinin klinik önemi ve hastalık seyri ile ilişkisi konusunda bilgimiz sınırlıdır. Bu çalışmanın amacı orta-ağır bronşiyolit tanısı ile hastaneye yatırılan ve eşlik eden başka hastalığı olmayan hastaların bazal plazma BNP değerleri ile sol ventrikül sistolik fonksiyonları ve hastalık prognozu arasındaki ilişkiyi araştırmaktır.

Yöntemler: Çalışmada bronşiyolit tanısı alan, modifiye Wang solunum skoru $\geq 6$ olan, 1-24 ay arasındaki 37 hasta ileriye dönük olarak incelendi. Plazma BNP düzeyi yüksek (>100 pg/mL, n=6) ve normal ( $\leq 100 \mathrm{pg} / \mathrm{mL}, \mathrm{n}=31)$ olan hastalar sol ventrikül sistolik işlevleri, yaşamsal bulgular, laboratuvar sonuçları ve radyolojik bulgular açısından karşılaştıııldı. Plazma BNP düzeyi ile prognoz arasındaki ilişki değerlendirildi.

Bulgular: Hastaların ortalama plazma BNP düzeyi, sağlıklı kontrol

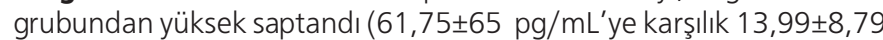
$\mathrm{pg} / \mathrm{mL}, \mathrm{p}=0,001)$. Plazma BNP düzeyi normal ve yüksek olan hastalar ile sağlıklı kontrol grubunun ejeksiyon fraksiyonu ve fraksiyonel kısalma değerleri arasında fark saptanmadı $(p>0,05)$. Plazma BNP düzeyi yüksek olan hastaların ortalama kısmi karbondioksit basıncı değeri, BNP düzeyi normal olan hastalardan yüksek bulundu $(p=0,037)$. Plazma BNP düzeyi ile hastanede yatış süresi $(r=0,286$; $p=0,007)$ ve yoğun bakımda yatış süresi $(r=0,645 ; p=0,000)$ arasında pozitif bir korelasyon saptandı.

Sonuç: Orta-ağır bronşiyolitli hastalarda miyokard işlev bozukluğu olmaksızın plazma BNP artışı görülebilir. Bu artış, hastalığa bağlı pulmoner gaz değişimindeki bozulmanın derecesi ile ilişkili olabilir. Plazma BNP düzeyi, orta-ağır bronşiyolitli hastalarda hastalık seyrini öngörmede potansiyel bir biyobelirteçtir.

Anahtar Kelimeler: Bronşiyolit, bebek, B-tipi natriüretik peptid, miyokard disfonksiyonu, prognoz

Address for Correspondence/Yazışma Adresi: Gülser Esen Besli MD, İstanbul Medeniyet University Göztepe Training and Research Hospital, Clinic of Pediatric Emergency, İstanbul, Turkey

Phone: +90 2165709355 E-mail: esenbesli@yahoo.com ORCID ID: orcid.org/0000-0001-6837-5384

Received/Geliș Tarihi: 04.11.2018 Accepted/Kabul Tarihi: 12.11.2018

${ }^{\circ}$ Copyright 2018 by Society of Pediatric Emergency and Intensive Care Medicine

Journal of Pediatric Emergency and Pediatric Intensive Care published by Galenos Yayınevi. 


\section{Introduction}

Acute bronchiolitis is the most common lower respiratory tract disease seen during infancy. It has been reported that although the frequency is not fully known, cardiac involvement may develop at varying degrees during this disease, which is caused by numerous viral agents, mainly respiratory syncytial virus (RSV). It is known that cardiac damage can occur in different degrees of severity, ranging from subclinical electrical and functional myocardial dysfunction to severe conduction disorders and widespread myocardial injury. ${ }^{1-5}$ Therefore, it is very important that the cardiac involvement which can develop in patients with acute bronchiolitis is not clinically overlooked and that it is detected early.

Symptoms and signs such as tachypnea, tachycardia, loss of appetite and fatigue, which are among the clinical findings of heart failure, can be seen in many patients diagnosed with bronchiolitis. Differential diagnosis of heart failure may become more difficult in patients with accompanied pneumonia who manifest rales in pulmonary auscultation. In recent years, plasma B-type natriuretic peptide (BNP) has been used more widely as a specific biomarker in the diagnosis of acute cardiac diseases and evaluating the prognosis and response to treatment in pediatric patients as well as in adults. ${ }^{6-11}$ Aside from heart diseases, BNP plasma levels have also been found to be elevated in acute bronchiolitis, which is involved in the differential diagnosis of dyspnea. ${ }^{11,12}$ However, our knowledge on the relation of BNP with prognosis in patients with isolated acute bronchiolitis is quite limited.

This study was conducted to determine the baseline plasma BNP levels, to assess the relationship between left ventricular systolic functions and plasma BNP levels, and to investigate the prognostic value of plasma BNP level in children aged 1 to 24 months who were diagnosed as having moderate to severe isolated bronchiolitis without additional disease in a pediatric emergency unit of a tertiary care hospital.

\section{Materials and Methods}

The present study was conducted prospectively on 37 patients hospitalized due to moderate-severe bronchiolitis during three bronchiolitis seasons between 2014 and 2017. This study was approved by the ethics committee of the hospital (Istanbul Medeniyet University Göztepe Training and Research Hospital, decision number: 2014/0132, date: 26.08.2014). Before enrollment in the study, parents of all patients were informed in detail about the study and their consent was obtained.

The diagnosis of bronchiolitis was made by evaluation of criteria including wheezing, restlessness, feeding difficulties, tachypnea, use of auxiliary respiratory muscles (all starting as prodromal symptoms of upper respiratory tract infection) in infants between 1 and 24 months of age and history of contact with an infected person or staying in day care homes. ${ }^{13}$ Modified Wang breathing score was used to determine the severity of the bronchiolitis. The respiratory score was evaluated as $\leq 5$ points: mild, $6-10$ points: moderate, and 10 points: severe bronchiolitis (see Appendix). ${ }^{14,15}$ Criteria for inclusion were as follows: patients who were between 1 and 24 months of age, who had bronchiolitis for the first time, and who had a modified Wang respiratory score of 6 or more. Those who were younger than 1 month and older than 24 months, who had a modified Wang respiratory score of less than 6, who had a history of prematurity, recurrent wheeze episodes or were diagnosed with asthma, who had acute or chronic renal insufficiency, a known or newly diagnosed structural cardiac disease, chronic pulmonary disease (such as cystic fibrosis, bronchopulmonary dysplasia), thyroid or pituitary gland disease, neuromuscular disease, and who received recent steroid treatment were excluded from the study. The demographic characteristics, physical examination findings, modified Wang respiratory scores, RSV results in nasopharyngeal swab, vital signs, basal plasma BNP levels, capillary blood gas, complete blood count (CBC), C-reactive protein and biochemical test results, pathological findings on chest X-ray (such as atelectasis, pneumonic infiltration, air leak), echocardiographic measurements, treatments given, length of hospital stay, and outcomes of each patient were

\begin{tabular}{|c|c|c|c|c|}
\hline *Points & 0 & 1 & 2 & 3 \\
\hline General appearance & Quiet, sleeping & $\begin{array}{l}\text { Crying when touched, but easy to } \\
\text { console }\end{array}$ & $\begin{array}{l}\text { Moderately irritable, } \\
\text { difficult to console }\end{array}$ & $\begin{array}{l}\text { Extremely irritable, lethargic, } \\
\text { poor feeding }\end{array}$ \\
\hline Chest sounds & $\begin{array}{l}\text { No crepitations, no } \\
\text { wheezing }\end{array}$ & $\begin{array}{l}\text { Diffuse crepitations or terminal } \\
\text { expiratory wheezing }\end{array}$ & Entire expiration wheezing & $\begin{array}{l}\text { Diffuse inspiratory and } \\
\text { expiratory wheezing }\end{array}$ \\
\hline Dyspnea & None & Mild (intercostal retractions) & $\begin{array}{l}\text { Moderate (tracheo-sternal } \\
\text { retractions) }\end{array}$ & $\begin{array}{l}\text { Severe (severe retractions with } \\
\text { nasal flaring) }\end{array}$ \\
\hline Respiratory rate & $<40 / \mathrm{bpm}$ & 40-55/bpm & 56-65/bpm & $>65 / \mathrm{bpm}$ \\
\hline Oxygen saturation & $>96 \%$ & $93-95 \%$ & $90-92 \%$ & $<90 \%$ \\
\hline
\end{tabular}


recorded. The chest X-rays of all patients were evaluated as single blind by a pediatric radiologist.

Basal plasma BNP levels of the patients were measured. The patients with high $(>100 \mathrm{pg} / \mathrm{mL})$ and normal $(\leq 100 \mathrm{pg} / \mathrm{mL})$ serum BNP levels were compared in terms of left ventricular systolic functions, and vital, laboratory, and radiological findings. To compare plasma BNP results, a "BNP control group" was created by using plasma residues of previously healthy 52 children aged between 1 and 24 months, who were admitted to the pediatric outpatient clinics before elective minor surgery and for whom a routine blood test was ordered by the physician. To compare echocardiographic measurement results of patients in the study group, echocardiographic measurement results of 40 healthy children were used; these control subjects were similar in age and were previously referred to the pediatric cardiology outpatient clinic because of innocent murmur and no structural or functional cardiac problems were found.

\section{Sampling and Study Technique for Plasma BNP Level}

The blood sample required for the measurement of plasma BNP levels of the patients was obtained at the time of access to the intravenous line and during drawing blood for the tests during the emergency room follow-up without any additional intervention and blood collection. Residues of blood drawn into vacuumed ethylene diamine tetraacetic acid tube for CBC were centrifuged at $4000 \mathrm{rpm} / 10 \mathrm{~min}$ and frozen at $-80{ }^{\circ} \mathrm{C}$ in the biochemistry laboratory. Plasma samples, collected from 37 patients, and 53 controls, were dissolved and the plasma BNP measurements were performed by the chemiluminescence microparticle immunoassay method by an Abbott architect ci4100 biochemistry autoanalyser using a 100-well Abbot Architect BNP Reagent Kit. 100 pg/mL was accepted to be the plasma BNP threshold value.

\section{Sampling and Study Technique for RSV Antigen}

RSV antigen examination of nasopharyngeal swabs was performed at bedside using a BD Directigen EZ RSV kit during emergency room follow-up. The results were obtained within 5-60 minutes.

\section{Echocardiography Examination and Echocardiographic Measurements}

Echocardiographic evaluations of the patients were performed by a pediatric cardiologist using a General Electric Vivid model echocardiography device with M mode 2-D Color Doppler method within the first 24 hours following the emergency department admission. Left ventricular end-diastolic diameter (LVEDd) and left ventricular end-systolic diameter (LVISd) were measured using parasternal long axis $M$ mode. The ejection fraction (EF\%) and the fractional shortening ( $\mathrm{Fs} \%)$ indicating left ventricular systolic functions were calculated automatically by the Teicholz formulation using the LVEDd and LVISd parameters (16).

\section{Statistical Analysis}

Demographic characteristics such as age and sex of the study and control groups were determined and comparison was made between the groups. The mean plasma BNP values in the study group and the healthy control group were determined and compared. The patients in the study group were divided into two subgroups of patients with normal BNP levels $(\leq 100 \mathrm{pg} / \mathrm{mL})$ and patients with high BNP levels $(>100$ $\mathrm{pg} / \mathrm{mL}$ ), and vital findings, laboratory results, and radiological findings were compared. Echocardiographic measurements (EF\%, $\mathrm{Fs} \%$ ) were compared between the study subgroups and the healthy control group. The relationship of plasma BNP level with intensive care need, length of intensive care unit stay, total length of hospital stay, need for noninvasive/ invasive mechanical ventilation, and in-hospital mortality were investigated. IBM SPSS Statistics 22 for statistical analysis (SPSS IBM, Turkey) program was used for evaluation of the findings obtained in this study. The normal distribution of parameters was analyzed by the Shapiro-Wilk test when the study data were evaluated. In the comparison of the descriptive statistical methods (mean, standard deviation) as well as the quantitative data, the Kruskal-Wallis test was used for comparison of non-normally distributed parameters between the groups and the Mann-Whitney $U$ test was used for the determination of the group causing the difference. The Student's t-test was used for the comparison of normally distributed parameters between two groups and the MannWhitney $U$ test was used for comparison of two groups with non-normal distribution parameters. Chi-square test, Fisher's exact test, Fisher-Freeman-Halton test and Continuity (Yates) correction were used for the comparison of qualitative data. Spearman's rho correlation coefficient was used in the analysis of the relationships between the parameters. Significance was evaluated at the level of $p<0.05$.

\section{Results}

Twenty-three (62.2\%) of the 37 patients in the study group were male, 14 (37.8\%) were female and the mean age was $6.19 \pm 4.94$ months. Forty-two cases in the healthy control group (45.7\%) were female, 50 (54.3\%) were male and the mean age was $7.44 \pm 3.85$ months. There was no difference between the study and control groups in terms of age and gender ( $p>0.05)$.

Although the mean plasma BNP level in the patients was within the normal limits, it was significantly higher than in the control group $(p=0.001, p<0.05)$ (Table 1). There was no clinical 
evidence of cardiac failure in the patients, and cardiomegaly was not detected on chest X-rays. Electrocardiography examinations showed no rhythm disturbances other than transient sinus tachycardia. Echocardiographic examination showed no left ventricular systolic dysfunction in any of the patients. There was no significant difference in EF\% and $\mathrm{Fs} \%$ mean values between the study and the healthy control groups ( $p>0.05$ ) (Table 2). Similarly, no significant difference was found in $\mathrm{EF} \%$ and $\mathrm{Fs} \%$ values between healthy controls and patients with normal $(\leq 100 \mathrm{pg} / \mathrm{mL})$ and high (>100 pg/ $\mathrm{mL}$ ) BNP levels ( $p>0.05$ ) (Table 3 ). There was no correlation between BNP levels and $\mathrm{EF} \%$ and $\mathrm{Fs} \%$ measurements of the patients $(r=-0,065, p=0,704$ and $r=-0,002, p=0,989$, respectively).

The mean age of the patients with high plasma BNP levels was lower than those with normal BNP levels $(p=0.018, p<0.05)$. However, there was no significant correlation between BNP level and age in the correlation analysis $(r=0.083, p=0.439)$. There was no sex difference between patients with normal and high BNP levels ( $p>0.05$ ).

There were no differences in respiratory rate, heart rate, oxygen saturation, body temperature, blood pressure, modified Wang respiratory score, chest X-ray findings, RSV positivity in nasal swabs, CBC, and biochemical values between the patients with normal and high plasma BNP levels ( $p>0.05)$. However,

Table 1. Comparison of plasma B-type natriuretic peptide level between patient and control groups

Plasma BNP level $(\mathrm{pg} / \mathrm{mL})$

mean \pm standard deviation

Patients $(n=37) \quad 61.75 \pm 65.15$

Control group $(n=52) \quad 13.99 \pm 8.79$

$\mathrm{p} \quad 0.001^{*}$

BNP: B-type natriuretic peptide, Mann-Whitney U test was used, ${ }^{*} p<0.05$

Table 2. Comparison of echocardiographic measurements between patient and control groups

\begin{tabular}{|lclc|}
\hline Measurements & $\begin{array}{l}\text { Patients } \\
(\mathbf{n}=\mathbf{3 7}) \\
\text { mean } \pm \text { SD }\end{array}$ & $\begin{array}{l}\text { Control group } \\
(\mathbf{n = 4 0 )}\end{array}$ & $\mathbf{p}$ \\
mean \pm SD & \\
\hline EF\% & $70.94 \pm 5.66$ & $69.83 \pm 4.61$ & 0.343 \\
\hline Fs\% & $37.89 \pm 4.49$ & $37.56 \pm 3.96$ & 0.735 \\
EF\%: Ejection fraction, Fs\%: Fractional Shortening, SD: Standard deviation, Student's \\
t-test was used, * $\mathrm{p}<0.05$.
\end{tabular}

patients with high BNP levels had lower mean blood $\mathrm{pH}$ values and higher mean partial carbon dioxide $\left(\mathrm{pCO}_{2}\right)$ values in blood gas analysis (Table 4).

There was no difference between the groups in terms of noninvasive and invasive mechanical ventilation requirements and in-hospital mortality when the patients with normal and high plasma BNP levels were compared with regard to disease course. The mean length of hospital stay in patients with higher BNP levels was longer than in patients with normal BNP levels, however, this difference was not statistically significant. Similarly, although the mean length of intensive care unit stay was longer in the group with higher BNP levels, this difference was not statistically significant (Table 5). However, correlation analysis revealed that there was a strong positive correlation between BNP level and length of hospital and intensive care unit stay $(r=0.286, p=0.007$ and $r=0.645$, $p=0.000$, respectively).

\section{Discussion}

Studies in the literature on plasma BNP levels in the pediatric population have been conducted mainly on the differential diagnosis of pulmonary diseases and cardiac diseases, monitoring the response of cardiac disease to treatment and prognosis. $9,17,18$ The number of studies evaluating BNP levels in primary lung diseases, such as bronchiolitis, is very scarce. We evaluated the relationship of basal plasma BNP levels with left ventricular systolic functions and disease prognosis in 37 patients with moderate to severe bronchiolitis who did not have any comorbidity. The mean BNP level in the patients was approximately four and a half times higher than in healthy children. Mild plasma BNP level elevation was found in six of the 37 patients (16.21\%). Echocardiography revealed no left ventricular systolic dysfunction in any of the patients. There was no statistically significant difference in $\mathrm{EF} \%$ and $\mathrm{Fs} \%$ values between the patients with normal and high BNP levels. This result suggests that an increase in plasma BNP levels may develop without myocardial dysfunction in patients with isolated acute bronchiolitis. Daneshmand et al. ${ }^{12}$ evaluated how N-terminal-proBNP, which is released from the ventricles in response to increased ventricular end-diastolic volume and pressure, is affected in patients with acute bronchiolitis. It was proposed that in these patients, preload of the left and

Table 3. Comparison of echocardiographic measurements between patient subgroups and control group

\begin{tabular}{|llll}
\hline & $\begin{array}{l}\text { Patients with normal } \\
\text { plasma BNP level }(\mathbf{n = 3 1 )}\end{array}$ & $\begin{array}{l}\text { Patients with high plasma } \\
\text { BNP level }(\mathbf{n = 6})\end{array}$ & Control group ( $\mathbf{n = 4 0 )}$ \\
Measurements & mean \pm SD & mean \pm SD & mean \pm SD \\
EF\% & $71.48 \pm 5.52$ & $68.17 \pm 6.11$ & $69.83 \pm 4.61$ \\
Fs\% & $38.39 \pm 4.1$ & $35.33 \pm 5.96$ & $37.56 \pm 3.96$ \\
BNP: B-type natriuretic peptide, EF\%: Ejection fraction, Fs\%: Fractional shortening, SD: Standard deviation, Kruskal Wallis test was used, * ${ }^{*}<0.05$ \\
\hline
\end{tabular}


right atria would be reduced due to systemic venous return associated with pulmonary hyperinflation and low levels of BNP would be found. However, plasma N-terminal-proBNP levels were found to be elevated from the time of admission until the end of the fifth day. Consistent with our results, the mean baseline N-terminal-proBNP values in 27 bronchiolitis patients were significantly (approximately two-fold) higher than in the controls. However, no comment was made about the reasons for this elevation and, the cardiac functions of the patients were not evaluated. In another study, baseline plasma BNP levels in 68 patients who were admitted to emergency unit with respiratory distress, of whom 49 had isolated bronchiolitis and 19 had congenital heart disease and bronchiolitis, were compared with that in controls. Similar to the results of our study, a slight increase in mean the plasma BNP level was found in patients with isolated bronchiolitis. However, the mean BNP level in patients with congenital heart disease and associated bronchiolitis was significantly higher than in those with isolated acute bronchiolitis. There was no correlation between plasma BNP levels of patients and respiratory rate, oxygen saturation, length of hospital stay and respiratory score. ${ }^{11}$ In our study performed on patients with isolated bronchiolitis only, no relationship of plasma BNP level with respiratory score and vital findings (body temperature, respiratory rate, heart rate, blood pressure, and oxygen saturation) was found. However, it is noteworthy that patients with higher BNP levels had higher mean $\mathrm{pCO}_{2}$ values in the baseline blood gas analysis. Therefore, it is thought that BNP increase without myocardial dysfunction may be related to disease-related pulmonary involvement and impairment in the gas exchange.

Table 4. Assessment of vital signs, laboratory and radiological findings of the patients with normal and high B-type natriuretic peptide levels

\section{Patients with normal plasma BNP level Patients with high plasma BNP level $\quad p$ \\ mean \pm SD \\ mean \pm SD}

RSV antigen in nasal swap

Negative

Positive

$\leq 10$

$>10$

Respiratory rate (min)

Heart rate $(\mathrm{min})$

$\mathrm{SpO}_{2}(\%)$

Temperature $\left({ }^{\circ} \mathrm{C}\right)$

SBP $(\mathrm{mmHg})$

DBP $(\mathrm{mmHg})$

$\mathrm{pH}$

$\mathrm{pCO}_{2}$

$\mathrm{HCO}_{3}$

Lactate

Hemoglobin

Leucocyte

Platelets

CRP

Ure

Creatinine

Sodium

Chest x-ray pathology

$\begin{array}{ll}\text { None } & 17(54.8 \%) \\ \text { Infiltration } & 12(38.7 \%) \\ \text { Atelectasis } & 2(6.5 \%)\end{array}$

$21(67.7 \%)$

$10(32.3 \%)$

$17(54.8 \%)$

$14(45.2 \%)$

$65 \pm 9.41$

$159.65 \pm 29.23$

$91.45 \pm 4.24$

$36.82 \pm 0.75$

$103.71 \pm 12.88$

$64.71 \pm 10.98$

$7.36 \pm 0.05$

$42.12 \pm 8.88$

$22.62 \pm 2.81$

$2.26 \pm 1.43$

$10.77 \pm 1.27$

$13021.43 \pm 4389.07$

$379200 \pm 144530.95$

$1.15 \pm 1.51$

$17.57 \pm 7.55$

$0.4 \pm 0.08$

${ }^{1} 0.173$

$4(66.7 \%)$

$2(33.3 \%)$

$4(66.7 \%)$

$65.67 \pm 12.99$

30.405

$167.5 \pm 18.91$

21.000

$89.83 \pm 6.08$

$36.77 \pm 0.59$

0.352

$88.5 \pm 16.26$

20.303

$67 \pm 24.04$

20.769

$7.27 \pm 0.05$

20.005 *

$54 \pm 13.19$

20.037 *

$22.63 \pm 2$

20.837

$2.65 \pm 1.2$

20.353

$11.56 \pm 1.67$

20.530

$15500 \pm 10527.35 \quad 20.980$

$316800 \pm 76040.78 \quad 20.315$

$0.53 \pm 1$

20.199

$11.6 \pm 9.81 \quad 20.106$

$0.4 \pm 0.03$

20.860

$136.8 \pm 3.56$

20.404

$137.86 \pm 2.59$

$4(66.7 \%)$

$2(33.3 \%)$

31.000

$0(0 \%)$
$2(33.3 \%)$

BNP: B-type natriuretic peptide, SBP: Systolic blood pressure, DBP: Diastolic blood pressure, $\mathrm{SpO}_{2}$ : Oxygen saturation, $\mathrm{HCO}$ : Bicarbonate, pH: Hydrogen ion concentration, pCO Partial carbon dioxide pressure, CRP: C-reactive protein

${ }^{1}$ Fisher's Exact test, ${ }^{2}$ Mann-Whitney $U$ test, ${ }^{3}$ Fisher Freeman Halton test were used, ${ }^{*} p<0,05$ 
In studies comparing the mean plasma BNP levels between healthy children and children who were admitted to the hospital with respiratory distress, BNP levels were slightly higher in children with pulmonary disease than in healthy controls, as in our study. However, the plasma BNP increase in acute cardiac diseases has been found to be much higher than the increase seen in pulmonary diseases. ${ }^{17,18}$ Evim et al. ${ }^{18}$ reported that a plasma BNP level of $726 \mathrm{pg} / \mathrm{mL}$ was the threshold value for differential diagnosis of heart failure and pulmonary diseases. Nevo et al. ${ }^{19}$ showed that mean plasma N-terminal proBNP levels in children with noncardiac diseases such as gastroenteritis, dehydration, and infectious diseases were significantly higher than in healthy children, but significantly lower than in children with cardiac diseases. It has been postulated that BNP release from myocytes might be induced as a result of increased cardiac output due to fever, and increased levels of circulating proinflammatory cytokines and stress hormones may stimulate BNP synthesis in these children. In our study, 6 of 37 patients (16\%) had fever, but no significant difference was found in body temperature between patients with high and normal plasma BNP level.

There are adult studies showing increased plasma BNP levels without left ventricular systolic dysfunction in patients with systemic inflammatory response, sepsis, and septic shock. ${ }^{20-22}$ Although unclear, it is believed that lipopolysaccharide and proinflammatory cytokines may increase BNP transcription and translation by direct toxic effect on cardiomyocytes. ${ }^{23}$ In our study, manifestations of clinical shock were not found in any of the patients. No difference was found between the patients with high and normal plasma BNP levels in terms of blood pressure, heart rate, and plasma lactate levels, which are indicative of hemodynamics and tissue perfusion. However, it is known that many viral agents, such as RSV, can activate proinflammatory cytokines in acute bronchiolitis. 22,2426 Therefore, it is thought that stimulation of cytokines due to viral factors may play a role in the increase of plasma BNP level in our cases.

Another important cause of increased plasma BNP levels involves the conditions where renal clearance is decreased. It has been shown that BNP levels are increased in patients with renal dysfunction..$^{27,28}$ It was thought that the increase in BNP was not due to renal origin since the children with renal disease had been excluded from our study, and absence of differences in urea and creatinine values between patients with high and normal BNP levels.

It has been shown that plasma BNP levels increased in parallel with disease severity in adult patients with pneumonia in the absence of heart failure. BNP levels were also found to be powerful predictors of death, treatment failure and shortand long-term mortality for adult patients with communityacquired pneumonia. ${ }^{29,30}$ Knowledge on the effect of BNP on prognosis in children with isolated bronchiolitis without myocardial dysfunction is very limited. In only a recent study on patients who were admitted to emergency room for acute isolated bronchiolitis, it was reported that clinical severity score and plasma BNP levels were independent risk factors for hospital admission, and there was a positive correlation between BNP levels and length of hospital stay. ${ }^{31}$

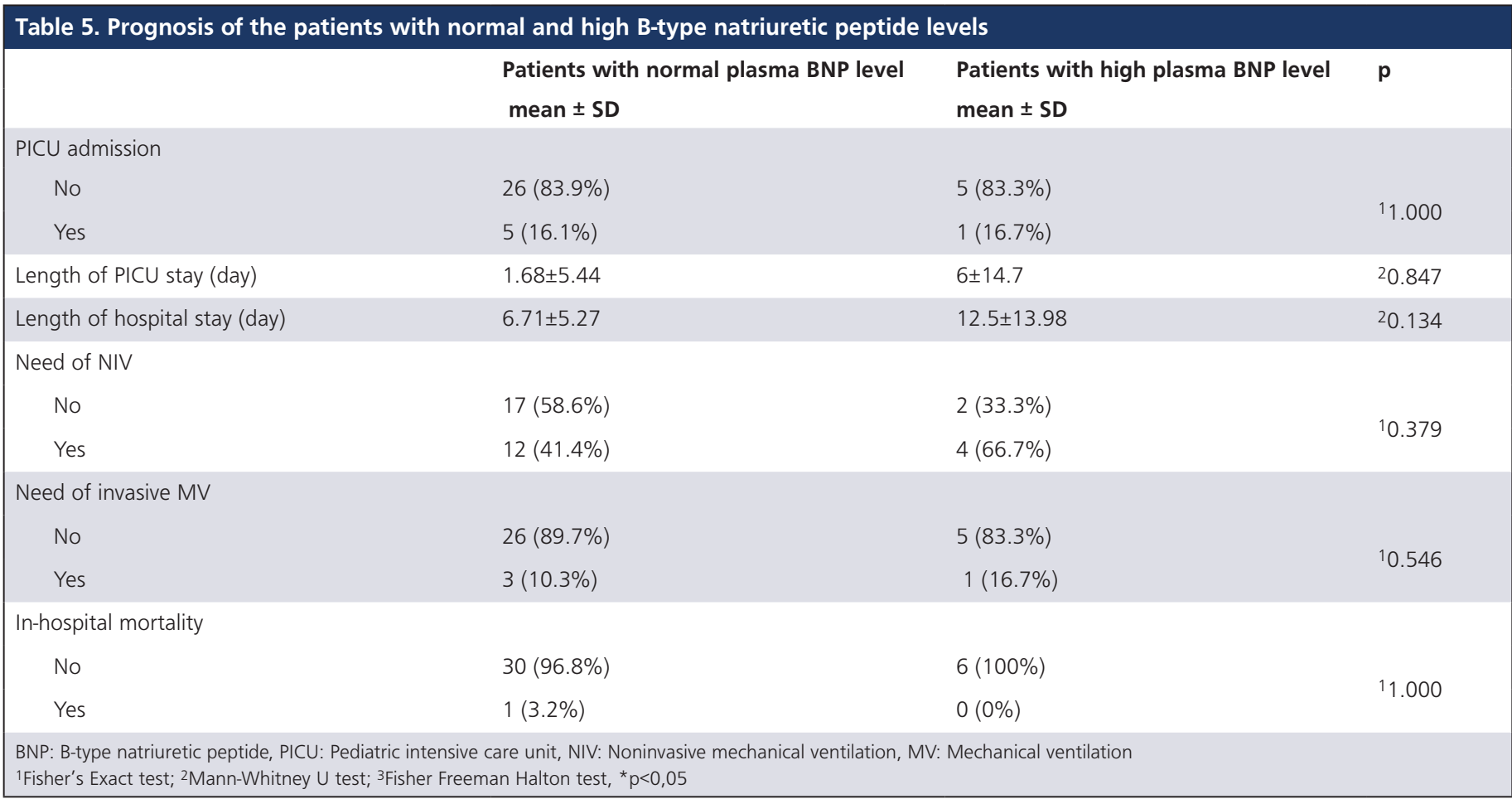


Our study included patients who were hospitalized with the diagnosis of moderate-severe isolated bronchiolitis. When the patients were evaluated for prognosis, there was no relationship of plasma BNP level with intensive care unit admission, noninvasive/invasive mechanical ventilation need and duration, and in-hospital mortality. However, there was a strong positive correlation between plasma BNP levels and length of total hospital and intensive care unit stay.

\section{Study Limitations}

In our study, serial plasma BNP measurements were not performed. For this reason, no comment was made on the change in BNP levels during the disease course. To compare $\mathrm{EF} \%$ and $\mathrm{Fs} \%$ measurement results of the patients, the results of echocardiography were used retrospectively in healthy children who had been addressed by the innocent murmur in the pediatric cardiology department and who did not have any structural or functional cardiac problems. These patients did not have simultaneous plasma BNP measurements. Therefore, for comparison of BNP values, a separate control group had to be formed by using plasma residues of healthy children of similar ages. The patients were evaluated only for left ventricular systolic function and no comment was made on right ventricular function and its relation with plasma BNP level.

\section{Conclusion}

Increased plasma levels of BNP can be seen without myocardial dysfunction in patients with acute isolated bronchiolitis. This increase may be related to disease-related pulmonary changes and impaired gas exchange. A positive relationship between plasma BNP levels and length of hospital stay and intensive care unit stay suggests that BNP is a potential prognostic marker in patients with moderate to severe bronchiolitis.

\section{Ethics}

Ethics Committee Approval Number: istanbul Medeniyet University Göztepe Training and Research Hospital, decision number: 2014/0132, date: 26.08.2014.

Informed Consent: Parents of all patients were informed in detail about the study and their consent was obtained.

Peer-review: Externally peer-reviewed.

\section{Authorship Contributions}

Surgical and Medical Practices: G.K., G.E.B., N.E., Y.I.A., F.K.I., Concept: G.E.B., Design: G.E.B., Data Collection or Processing: G.K., G.E.B., Analysis or Interpretation: G.K., G.E.B., Literature Search: G.K., G.E.B., Writing: G.K., G.E.B.

Conflict of Interest: No conflict of interest was declared by the authors.
Institutional and Financial Support: This study was supported by the Medeniyet University Scientific Research Projects Fund (Project Code: T-UZM-2015-676).

\section{References}

1. Checchia PA, Appel HJ, Kahn S, Smith FA, Shulman ST, et al. Myocardial injury in children with respiratory syncytial virus infection. Pediatr Crit Care Med. 2000;1:146-50.

2. Huang $M$, Bigos $D$, and Levine $M$. Ventricular arrhythmia associated with respiratory syncytial viral infection. Pediatr Cardiol. 1998; 19:498-500.

3. Armstrong D and Menahem S. Cardiac arrhythmias as a manifestation of acquired heart disease in association with paediatric respiratory syncitial virus infection. J Paediatr Child Health. 1993;29:309-11.

4. Menchise A. Myocarditis in the setting of RSV bronchiolitis. Fetal Pediatr Pathol 2011;30:64-8.

5. Eisenhut $M$, Sidaras $D$, Johnson $R$, Newland $P$, and Thorburn $K$. Cardiac troponin $T$ levels and myocardial involvement in children with severe respiratory syncytial virus lung disease. Acta Paediatr. 2004;93:887-90

6. Akcan $A B$ and Oygur N. Brain natriuretic peptide and applications in pediatrics/Beyin natriuretik peptid ve pediatride kullanim alanlari. J Current Pediatrics. 2010;8:67-72.

7. Berger R, Huelsman M, Strecker K, Bojic A, Moser P, et al. B-Type Natriuretic Peptide Predicts Sudden Death in Patients With Chronic Heart Failure. Circulation. 2002;105:2392-97.

8. Davis GK, Bamforth F, Sarpal A, Dicke F, Rabi Y, et al. B-type natriuretic peptide in pediatrics. Clin Biochem. 2006;39:600-5.

9. Hammerer-Lercher A, Geiger R, Mair J, Url C, Tulzer G, et al. Utility of $\mathrm{N}$-terminal pro-B-type natriuretic peptide to differentiate cardiac diseases from noncardiac diseases in young pediatric patients. Clin Chem. 2006;5:1415-19.

10. Kalra PR, Anker SD, and AJS Coats. Water and sodium regulation in chronic heart failure: the role of natriuretic peptides and vasopressin. Cardiovasc Res. 2001;51:495-509.

11. Sahingozlu T, Karadas U, Eliacik K, Bakiler AR, Ozdemir Karadas N, et al. Brain natriuretic peptide: the reason of respiratory distress is heart disease or lung disease? Am J Emerg Med. 2015;33:697700 .

12. Daneshmand KA, Zaritsky AL, Lamb MA, LeVine AM, Sanders RC. Plasma concentration of $\mathrm{N}$-terminal pro-atrial and $\mathrm{N}$-terminal pro-brain natriuretic peptides and fluid balance in children with bronchiolitis. J Ped Intensive Care. 2012;3:143-51.

13. Coates BM, Camarda LE, and Goodman DM. Wheezing in Infants: Bronchiolitis. 2044-2048. In: Kliegman S, Stanton BF, St Geme JW, Schor NF (Eds). Nelson Textbook of Pediatrics (20th Ed). Philadelphia, PA: Elsevier, 2016.

14. Wang EE, Milner RA, Navas L, Maj H. Observer agreement for respiratory signs and oximetry in infants hospitalized with lower respiratory infections. Am Rev Respir Dis. 1992;145:106-9.

15. Bressan S, Balzani M, Krauss B, Pettenazzo A, Zanconato S, et al. High-flow nasal cannula oxygen for bronchiolitis in a pediatric ward: a pilot study. Eur J Pediatr. 2013;172:1649-56.

16. Teichholz LE, Cohen MV, Sonnenblick EH, and Gorlin R. Study of left ventricular geometry and function by B-scan ultrasonography in patients with and without asynergy. N Engl J Med. 1974;291:1220-26. 
17. Cohen S, Springer C, Avital A, Perles Z, Rein AJ, et al. Aminoterminal pro-brain-type natriuretic peptide: heart or lung disease in pediatric respiratory distress? Pediatrics. 2005;115:1347-50.

18. Evim MS, Uçar B, Kiliç Z, and Colak OF. The value of plazma N-terminal pro-brain natriuretic peptide levels in the differential diagnosis and follow-up of congestive cardiac failure and respiratory distress due to pulmonary aetiologies in infants and children. Cardiol Young. 2010;20:495-504.

19. Nevo I, Erlichman M, Algur N, and Nir A. N-terminal pro B-type natriuretic peptide levels in infants and children with acute noncardiac diseases. Isr Med Assoc J. 2011;13:420-24.

20. Shor R, Rozenman Y, Bolshinsky A, Harpaz D, Tilis Y, et al. BNP in septic patients without systolic myocardial dysfunction. Eur J Intern Med 2006;17:536-40.

21. Piechota M, Barylski M, Hannam S, Mikhailidis DP, Rysz J, et al. Natriuretic peptides in septic patients. Curr Med Chem. 2009;16:4020-31.

22. Klouche K, Pommet S, Amigues L, Bargnoux AS, Dupuy AM, et al. Plasma brain natriuretic peptide and troponin levels in severe sepsis and septic shock: relationships with systolic myocardial dysfunction and intensive care unit mortality. J Intensive Care Med. 2014;29:229-37.

23. Tomaru KK, Arai M, Yokoyama T, Aihara Y, Sekiguchi KK, et al. Transcriptional activation of the BNP gene by lipopolysaccharide is mediated through GATA elements in neonatal rat cardiac myocytes. J Mol Cell Cardiol. 2002;34:649-59.

24. Matsuda K, Tsutsumi H, Okamoto $Y$, and Chiba C. Development of interleukin 6 and tumor necrosis factor alpha activity in nasopharyngeal secretions of infants and children. Development of interleukin 6 and tumor necrosis factor alpha activity in nasopharyngeal secretions of infants and children during infection with respiratory syncytial virus. Clin Diagn Lab Immunol. 1995;2:322-24.

25. Noah TL, Henderson FW, Wortman IA, Devlin RB, Handy J, et al. Nasal cytokine production in viral acute upper respiratory infection of childhood. J Infect Dis. 1995; 171:584-92.

26. Fried I, Bar-Oz B, Algur N, Fried E, Gavri S, et al. Comparison of $\mathrm{N}$-terminal pro-B-type natriuretic peptide levels in critically ill children with sepsis versus acute left ventricular dysfunction. Pediatrics. 2006;118:1165-68.

27. Cowie MR and GF Mendez. BNP and congestive heart failure. Prog Cardiovasc Dis. 2002;44:293-321.

28. Takami Y, Horio T, Iwashima Y, Takiuchi S, Kamide K, et al. Diagnostic and prognostic value of plasma brain natriuretic peptide in nondialysis-dependent CRF. Am J Kidney Dis. 2004;44:420-28.

29. Christ-Crain M, Breidthardt T, Stolz D, Zobrist K, Bingisser R, et al. Use of B-type natriuretic peptide in the risk stratification of community-acquired pneumonia. J Intern Med. 2008;264:166-76.

30. Nowak A, Breidthardt T, Christ-Crain M, Bingisser R, Meune C, et al. Direct comparison of three natriuretic peptides for prediction of short- and long-term mortality in patients with community-acquired pneumonia. Chest. 2012;141:974-82.

31. Anıl M, Göç Z, Avcı R, Gökalp G, Bıcılıoğlu Y, et al. B-type natriuretic peptide is a useful biomarker predicting disease severity in children with isolated bronchiolitis in the emergency department. Turk J Pediatr. 2017;59:561-69. 